\title{
Growth and somatomedin responses to growth hormone in Down's syndrome
}

\author{
G ANNERÉN, V R SARA, K HALL, AND T TUVEMO
}

Departments of Clinical Genetics and Paediatrics, University of Uppsala, Akademiska Hospital, Uppsala, Department of Psychiatry, St Göran's Hospital, Stockholm, and Department of Endocrinology, Karolinska Hospital, Stockholm, Sweden

SUMMARY Five growth retarded children with Down's syndrome, three girls and two boys aged between $31 / 2$ and $61 / 2$ years with trisomy 21 , were treated with human growth hormone for six months. Before treatment the growth hormone response to sleep and insulin-arginine load, as well as serum concentrations of insulin, thyroid hormones, and cortisol was found to be in the normal range. During the treatment with human growth hormone the growth velocity increased in all the children with Down's syndrome from $2 \cdot 3-2.8 \mathrm{~cm}$ to $3.3-5.8 \mathrm{~cm}$ per six months. The serum concentrations of immunoreactive insulin like growth factor 1 (IGF-1) were low before treatment and increased during the treatment with human growth hormone. The serum concentrations of immunoreactive insulin like growth factor 2 (IGF-2), which were within the normal range, however, increased during treatment with human growth hormone. Children with Down's syndrome respond to treatment with human growth hormone, with an increase in both growth velocity and serum somatomedin concentrations.

Growth retardation and development of presenile dementia are characteristic features of Down's syndrome. Even if the basic defect, trisomy for chromosome 21 , is well defined, little is known about the mechanisms causing growth retardation, mental retardation, and the other abnormalities.

Somatomedins have been proposed as regulating growth, including brain growth, ${ }^{1}$ and being altered in mental retardation due to disturbances in brain development. ${ }^{2}$ Several studies have examined the role of somatomedins in Down's syndrome. ${ }^{3-5}$ Patients with Down's syndrome show a deficiency in serum insulin like growth factor 1 (IGF-1). This growth hormone dependent somatomedin fails to rise during childhood and remains at a low concentration throughout life. ${ }^{3}$ The serum concentration of insulin like growth factor 2 (IGF-2) in patients with Down's syndrome is, however, within the normal range, ${ }^{5}$ and the receptors for somatomedins and insulin in fetuses with Down's syndrome have been found to be normal. ${ }^{4}$ Determination of serum somatomedins by a radioreceptorassay proposed to detect a fetal form of somatomedin showed scarcely detectable concentrations in fetuses with Down's syndrome ${ }^{6}$ but raised concentrations throughout postnatal life. ${ }^{3}$ A delayed maturation and incomplete switching from production of a fetal form of somatomedin to the IGF-1 regulated by growth hormone was suggested in patients with Down's syndrome.

Growth becomes dependent on growth hormone during the first year of life. At this time growth hormone begins to regulate the production of somatomedin. ${ }^{7}$ The concentration of growth hormone has been reported to be in the normal range in patients with Down's syndrome. ${ }^{8}$ Some trials with treatment with growth hormone in patients with Down's syndrome have been performed. However, these studies used animal growth hormone and even a peroral route for administration, and thus the results are inconclusive. ${ }^{9}$ The current belief therefore is that children with Down's syndrome do not respond to human growth hormone.

The aim of this investigation was to study if somatomedin concentrations, especially IGF-1, and growth velocity in children with Down's syndrome substantially increased on treatment with standard dosages of parenterally given human growth hormone.

\section{Methods}

Subjects (Table 1). Five children, three girls and two boys of ages $31 / 2$ and $61 / 2$ years with trisomy 21 , but 
without clinically important congenital malformation, were chosen. None were malnourished or had any deviation in dietary habit or food preferences. They were all cared for by their biological parents. None of them had had any severe infectious disease or had been taking any drug during the last year before or during the treatment with human growth hormone. All had profound growth retardation with a height $>3$ SD below the mean according to the Swedish standard, ${ }^{10}$ but they did not deviate further from the $-3 \mathrm{SD}$ channel of the growth chart the last year before treatment. The parents were all of normal height, except for the mother of case 4 , who was $1.50 \mathrm{~m}$.

Laboratory investigations before treatment with human growth hormone. Glucose clearance after intravenous glucose load $(0 \cdot 3 \mathrm{~g} / \mathrm{kg}$ birthweight $)$ was within the normal range in all cases (half life 28-54 minutes). Thyroid hormone assays (thyroid stimulating hormone, triiodothyronine, and thyroxine) were all within normal reference limits. Plasma cortisol concentration was measured after insulin stimulation and was found to be within normal limits in all cases $(660-1100 \mathrm{nmol} / \mathrm{l}(23 \cdot 9-39-8 \mu \mathrm{g} / 100 \mathrm{ml})$ ).

Concentrations of immunoreactive growth hormone were determined by a radioimmunosorbent technique ${ }^{11}$ using human pituitary growth hormone (Kabi AB, Stockholm) for labelling and rabbit antihuman pituitary growth hormone. The results were expressed in $\mu \mathrm{g} / \mathrm{l}$ using the World Health Organisation International Reference Preparation of Growth Hormone, 66/217, as a reference. ${ }^{11}$ The secretion of growth hormone was evaluated during sleep and after an arginine-insulin load. Four of the children showed a peak value of at least $16 \mu \mathrm{g} / \mathrm{l}$ in one of the tests; case 4 had a maximal peak value of $8 \cdot 8 \mu \mathrm{g} / \mathrm{l}$ (Table 2).

Somatomedin assays. The concentrations of somatomedins were determined by two radioimmunoassays. The radioimmunoassay for IGF-1, which allows determination in whole serum, has been described previously. ${ }^{12}$ This assay measures predominantly IGF-1, and IGF-2 crossreacts only $1 \%$. The arbitrary local reference serum used as standard contained $180 \mathrm{ng}$ of IGF- $1 / \mathrm{ml}$.

The radioimmunoassay for IGF-2, with sepharose coupled antibodies and pure IGF-2 as ligand was used. ${ }^{13}$ The crossreaction of IGF-1 varied between 8 and $10 \%$. The immunoreactive IGF-2 values are given for acid ethanol extracted serum. The results are expressed in ng equivalents of IGF-2 and corrected for the crossreaction of IGF-1. The

Table 1 Clinical characteristics of five children with Down's syndrome with growth retardation, before and after six months' treatment with $0.5 \mathrm{U} / \mathrm{kg} /$ week of human growth hormone

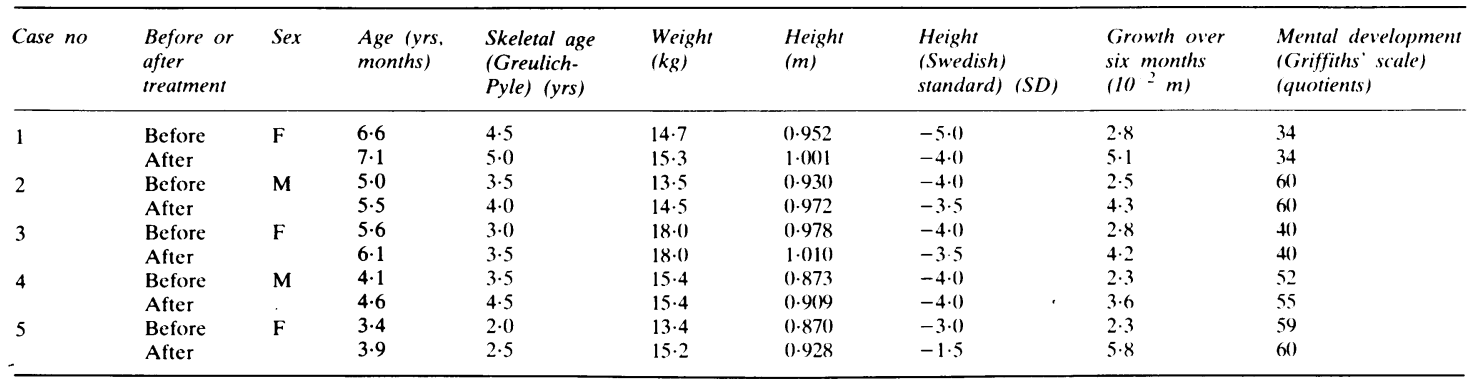

Table 2 Concentrations of plasma growth hormone $(\mu \mathrm{g} / \mathrm{l})$ during sleep and the insulin-arginine loading test in five patients with Down's syndrome, before treatment with growth hormone

\begin{tabular}{|c|c|c|c|c|c|c|c|c|c|c|c|c|}
\hline \multirow[t]{2}{*}{ Case no } & \multicolumn{5}{|c|}{$\begin{array}{l}\text { Sleep test } \\
\text { Time (mins) }\end{array}$} & \multicolumn{7}{|c|}{$\begin{array}{l}\text { Insulin-arginine loading test } \\
\text { Time (mins) }\end{array}$} \\
\hline & 0 & 30 & 60 & 90 & 120 & 0 & 30 & 60 & 9() & 120 & 150 & 180 \\
\hline 1 & $55 \cdot 0$ & $25 \cdot 0$ & $12 \cdot 4$ & $4 \cdot 8$ & $9 \cdot 3$ & $2 \cdot 3$ & $3 \cdot 2$ & $16 \cdot 7$ & 6.4 & $13 \cdot 8$ & $16 \cdot 5$ & $13 \cdot 0$ \\
\hline 2 & $16 \cdot 7$ & $6 \cdot 4$ & $3 \cdot 3$ & 1.7 & $2 \cdot 7$ & 4.2 & 1.5 & 1.9 & $3 \cdot 3$ & $9 \cdot 7$ & $13 \cdot 7$ & $13 \cdot 2$ \\
\hline 3 & $5 \cdot 2$ & $2 \cdot 2$ & $3 \cdot 5$ & $1 \cdot 5$ & & $2 \cdot 1$ & $7 \cdot 1$ & 1.4 & 9.5 & $12 \cdot 3$ & 11.4 & 19.9 \\
\hline 4 & & $6 \cdot 2$ & 8.8 & $8 \cdot 6$ & $5 \cdot 4$ & & 1.9 & $4 \cdot 4$ & 5.4 & $3 \cdot 4$ & & \\
\hline 5 & & $9 \cdot 6$ & $4 \cdot 7$ & $2 \cdot 7$ & $6 \cdot 0$ & 11.8 & 5.7 & $11 \cdot 8$ & 18.4 & 7.9 & $16 \cdot 5$ & $20 \cdot 0$ \\
\hline
\end{tabular}


arbitrary local reference serum used as standard was shown to contain $980 \mathrm{ng}$ of IGF-2/ml after correction for its content of IGF-1.

Growth hormone loading test. A daily dose of 0.08 $\mathrm{U} / \mathrm{kg}$ body weight of human growth hormone (Crescormon, KabiVitrum) was administered subcutaneously at 1900 during 10 days in hospital, according to Rudman et al. ${ }^{14}$ Serum immunoreactive IGF-1 and IGF-2 concentrations were determined by radioimmunoassay on 0,5 , and 10 days of the human growth hormone loading test. All serum samples were immediately frozen at $-20^{\circ} \mathrm{C}$ until assayed.

Growth hormone treatment. After the human growth hormone loading test the children with Down's syndrome were treated at home with 0.5 $\mathrm{U} / \mathrm{kg}$ week of human growth hormone (Crescormon, KabiVitrum), divided into three doses given at bedtime. Height and weight measurements were performed monthly by the same physician, and the average of three readings was recorded at each visit. Height was measured on a Stadiometer mounted on a wall. Blood samples for somatomedin assays were drawn once monthly between 0930 and 1100 . Before and after the six months of treatment with human growth hormone, examinations of the mental development according to Griffiths' mental development scale $e^{15}$ and of the skeletal maturation according to the method of Greulich and Pyle ${ }^{16}$ were performed.

Results were expressed as mean \pm 1 standard deviation (SD). Because of the small number of patients no significance test was performed.

\section{Results}

Growth and development. All the patients increased their growth velocity during treatment with human growth hormone (Table 1). The increase of the growth velocity ranged from roughly $50 \%$ to $200 \%$. The growth velocity during treatment ranged between 3.3 and $5.8 \mathrm{~cm}$ each six months (mean (SD) $4.5(1.0) \mathrm{cm})$ compared with $2.3-2.8 \mathrm{~cm}(2.5(0.3)$ $\mathrm{cm}$ ) before treatment and $1.5-4.0 \mathrm{~cm}(2 \cdot 6(1 \cdot 0) \mathrm{cm})$ after treatment (Fig. 1). The skeletal maturation of the children with Down's syndrome was retarded by about one and a half years, according to the method of Greulich and Pyle, ${ }^{16}$ both before and after treatment with human growth hormone (Table 1). Quotients according to Griffiths' mental development scale ${ }^{15}$ before and after treatment with human growth hormone did not show any differences.

Serum somatomedins. In all the patients the serum

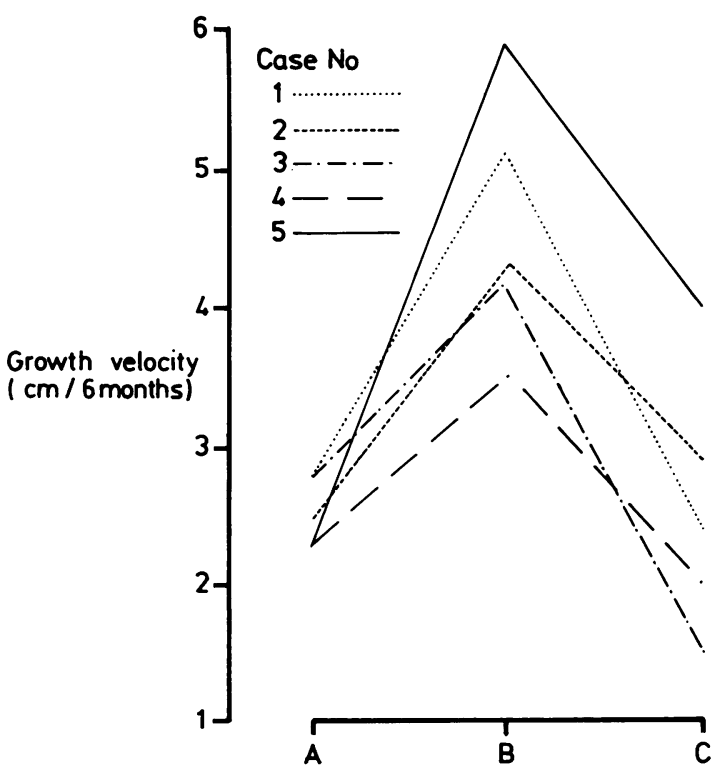

Fig. 1 Growth $(\mathrm{cm})$ during six month periods in five children with Down's syndrome $(A)$ before; $(B)$ during; and $(C)$ after six months' treatment with $0.5 \mathrm{U} / \mathrm{kg} /$ week human growth hormone.

concentration of immunoreactive IGF-1 increased during the ten days of loading with human growth hormone (Fig. 2). The increase from concentration before treatment ranged from $46 \%$ to $234 \%$. Concentrations before treatment $(62 \cdot 3(17 \cdot 5) \mathrm{ng} / \mathrm{ml})$ were low and ranged between -2 and -1 SD below the normal concentration in children of this age (2-4 years: $121(38) \mathrm{ng} / \mathrm{ml}$; 4-6 years: $126(64) \mathrm{ng} / \mathrm{ml}) .^{17}$ The mean immunoreactive IGF-1 concentration increased to normal $(125.6(48 \cdot 3) \mathrm{ng} / \mathrm{ml})$ after 10 days of treatment and ranged from -1 to $+1.5 \mathrm{SD}$ of the control value. During the six months of treatment with human growth hormone the concentrations remained above that before treatment in all patients (Fig. 3). The increases in serum immunoreactive IGF-1 concentrations six months after the start of treatment with human growth hormone ranged from $37 \%$ to $224 \%$ of the concentrations before treatment. The maximal concentration during treatment of one patient (case 5) was even greater than $+3 \mathrm{SD}$ above mean for age.

In all patients the serum concentrations of immunoreactive IGF-2 increased during the loading test (Fig. 2). The increases from values before treatment ranged from $30 \%$ to $108 \%$. Concentrations before treatment lay between $-2 \mathrm{SD}$ and -1 SD below the mean in normal adults (606 (158) $\mathrm{ng} / \mathrm{ml}^{13}$ ) and after 10 days of treatment between -1 


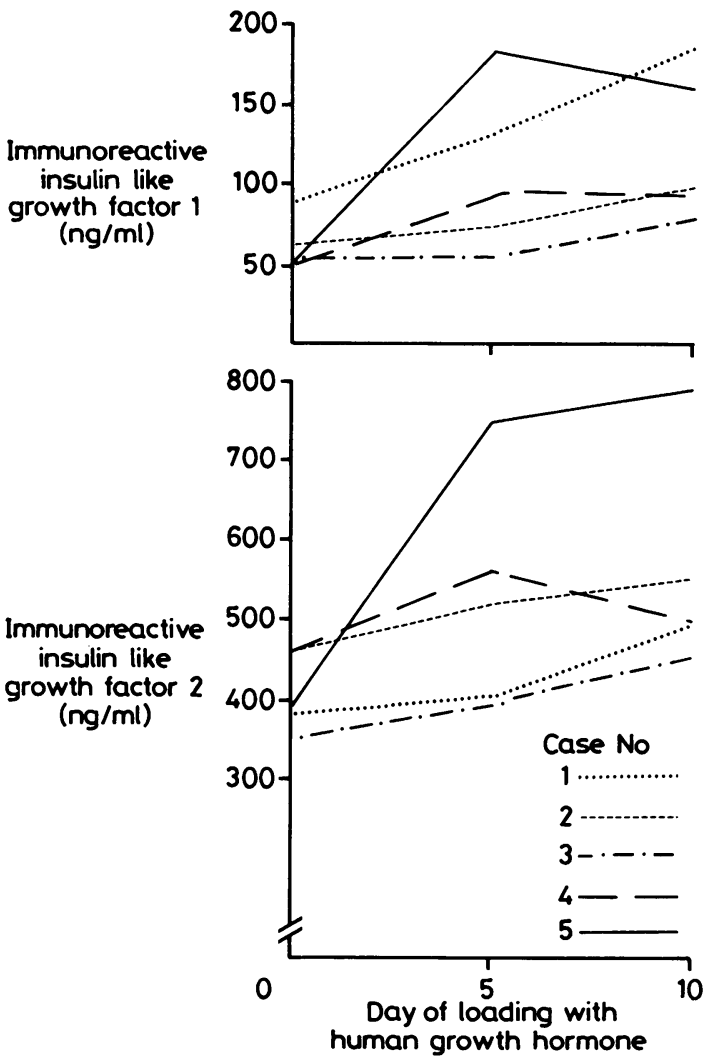

Fig. 2 Serum somatomedins $(\mathrm{ng} / \mathrm{ml})$ determined by radioimmunoassays for IGF-I (upper panel) and IGF-2 (lower panel) during 10 days of human growth hormone loading $(0.08 \mathrm{U} / \mathrm{kg} /$ day) in five children with Down's syndrome. Serum immunoreactive IGF-I and IGF-2 concentrations were determined on 0,5 , and 10 days of the human growth hormone loading test.

and $+1 \cdot 5$ SD. The immunoreactive IGF-2 concentrations remained raised during treatment (Fig. 3), and in two patients (cases 4 and 5) the maximum concentrations during treatment were increased to more than $+3 \mathrm{SD}$ from normal. The increases in serum immunoreactive IGF-2 concentrations at the end of the six months' treatment with human growth hormone ranged between $15 \%$ and $176 \%$ of the concentrations before treatment.

There were great individual variations both in the time of occurrence of the peaks and in the magnitude of immunoreactive IGF-1 and IGF-2 responses to treatment with human growth hormone (Fig. 3). Comparison of individual responses (Figs. 1 and 3 ) showed a relation between maximal responses of immunoreactive IGF-1 and increase in growth velocity.
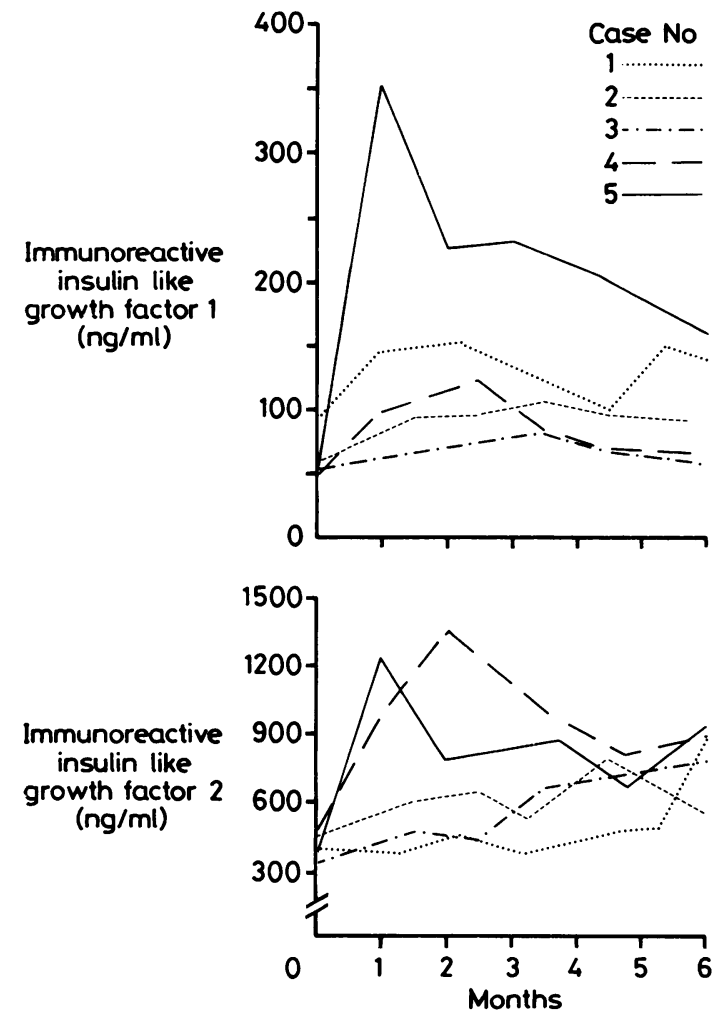

Fig. 3 Serum somatomedins $(\mathrm{ng} / \mathrm{ml})$ determined by radioimmunoassays of IGF-I (upper panel) and IGF-2 (lower panel) during six months' treatment with 0.5 $U / \mathrm{kg} /$ week human growth hormone in five children with Down's syndrome. Serum immunoreactive IGF-I and $I G F-2$ concentrations were determined monthly from months 0-6 of treatment.

\section{Discussion}

Earlier studies have shown that, similar to pygmies, ${ }^{18}$ children with Down's syndrome have a selective deficiency of serum IGF-1 concentrations. ${ }^{3} 5$ From the present results it is clear that children with Down's syndrome respond to treatment with human growth hormone. The growth velocity increased considerably during the six months of treatment in all the patients. This is remarkable, as the growth velocity before treatment was within the normal range for healthy children at this age and height. Skeletal retardation was observed in the present patients. There was no difference between the skeletal retardation before and after treatment, crudely indicating that no acceleration of the maturation accompanied the growth spurt. The 
concentrations of the IGF-1 like peptide determined by radioimmunoassay were low before treatment in all the patients and increased after 10 days of loading with human growth hormone to normal for this age group. Although the IGF-2 values were within the normal range, immunoreactive IGF-2 concentrations also increased promptly on treatment. The individual increases in these children with Down's syndrome suggested a relation between growth velocity and the growth hormone dependent somatomedin IGF-1.

Although the present findings suggest deficiency of growth hormone, children with Down's syndrome seem to have reasonable endogenous growth hormone concentrations, as evaluated from two accepted clinical standard test procedures in the present patients, as well as from earlier reports. ${ }^{8}$ Hayek and Peake ${ }^{19}$ classified children with short stature into three groups. Group 1 comprised the children deficient in growth hormone and groups 2 and 3 both comprised children with normal serum growth hormone concentrations and low somatomedin C (IGF-1) concentrations. The children of group 2 responded with increased velocity of growth and increased concentrations of somatomedin treatment with human growth hormone, while the children of group 3-that is, the Laron dwarfs-with a growth hormone receptor failure ${ }^{20}$ did not respond at all. Patients with Down's syndrome, thus, could be classified in group 2. Before a partial growth hormone insufficiency can be eliminated in patients with Down's syndrome, however, further studies will be required to determine their pattern of secretion of growth hormone over 24 hours to evaluate a possible 'relative' growth hormone deficiency.

This study shows that children with Down's syndrome increase their growth velocity during six months' treatment with human growth hormone, but does by no means prove that short term (or long term) treatment with human growth hormone increases final height in these children. Even if the delay in skeletal maturation during the six months was unchanged, it has to be considered that skeletal maturation as measured by most routine methods is very crude, while in the long run increased growth and maturation could well be parallel. After treatment growth velocity essentially returned to values before treatment.

We thank Leif Wide for help and discussions concerning the growth hormone determinations and Lena Löwenhjelm for performing the Griffiths' tests. This study was supported by grants from the Sävstaholms Society, Riksbanken Jubileumsfond, and the Swedish Medical Research Council (Project No's 4224, 5445, and 6825).

\section{References}

I Sara VR, Hall K, Wetterberg L. Fetal brain growth: a proposed model for regulation by embryonic somatomedin. In: Ritzén $M$, Aperia A, Hall K, Larsson A. Zetterberg A, Zetterström R. eds. The biology of normal human growth. New York: Raven Press, 1981:241-53.

2 Sara VR, Hall K, Rutter M, Wetterberg L, Yuwiler A Hormonal regulation of brain growth: implications for mental retardation. In: Perris C. Struwe G, Jansson B, eds. Biological psychiatry. Nth Holland: Elsevier, 1981:1316-9.

3 Sara VR, Gustavson K-H. Annerén G, Hall K. Wetterberg L. Somatomedins in Down's syndrome. Biol Psychiatry 1983;18:803-11.

+ Sara VR, Sjögren B, Annerén G, et al. The presence of normal receptors for somatomedin and insulin in fetuses with Down's syndrome. Biol Psychiatry 1984;19:591-8.

5 Annerén G. Enberg G, Sara VR. The presence of normal levels of serum immunoreactive insulin-like growth factor 2 (IGF-2) in patients with Down's syndrome. Ups J Med Sci 1984;89:274-8.

- Sara VR, Hall K, Rodeck CH, Wetterberg. Human embryonic somatomedin. Proc Natl Acad Sci 1981;78:741-8.

${ }^{7}$ Hall K, Sara VR. Growth and somatomedins. Vitamins and Hormones 1983;40:175-233.

${ }^{8}$ Ruvalcaba RHA. Thuline HC, Kelley VC. Plasma growth hormone in patients with chromosomal anomalies. Arch Dis Child 1972:47:307-9.

9 Berg JM, Kirman BH, Stern J. Treatment of mongolism with pituitary extract. Journal of Mental Science 1961:107:474-80.

${ }^{10}$ Karlberg P, Taranger J, Engström J, et al. Physical growth from birth to 16 years and longitudinal outcome of the study during the same period. Acta Paediatr Scand 1976;Suppl 258.

11 Wide L. Radioimmunoassay employing immunosorbents. Acta Endocrinol /Suppl/ (Copenh) 1969;142:207-21.

12 Hall K, Brandt J, Enberg G. Fryklund L. Immunoreactive somatomedin A in human serum. J Clin Endocrinol Metab 1979;48:271-5.

13 Enberg G, Hall K. Immunoreactive IGF-2 in serum of healthy subjects and patients with growth hormone disturbances and uremia. Acta Endocrinol (Copenh) 1985; in press.

${ }^{14}$ Rudman D, Kutner MH, Blackston RD, Cushman RA, Bain RP, Patterson JH. Children with normal-variant shor stature: treatment with human growth hormone for six months $N$ Engl J Med 1981;305:123-31.

is Alin-A kerman B, Nordberg L. Griffiths' utvecklingsskalor I och II. Manual för administrering och utvärdering. Eskilstuna. Sweden, Psykologiförlaget AB, 1980.

${ }^{16}$ Greulich WW, Pyle SJ. Radiographic atlas of skeletal development of hand and wrist. Stanford: Stanford University Press. 1959.

${ }^{17}$ Hall K, Enberg G, Ritzén M, Svan H, Fryklund L, Takano K. Somatomedin A levels in serum from healthy children and from children with growth hormone deficiency or delayed puberty. Acta Endocrinol (Copenh) 1980;94:155-65.

${ }^{18}$ Merimee TJ, Zapf J, Froesch ER. Dwarfism in the pygmy. An isolated deficiency of insulin-like growth factor 1. N Engl J Med 1981;305:965-8.

19 Hayek A, Peake GT. Growth and somatomedin-C responses to growth hormone in dwarfed children. Pediatrics 1981;99:868-71.

20 Laron Z, Pertzelan A, Karp M, Kowadlo-Sibergeld A, Daughaday WH. Administration of growth hormone to patients with familial dwarfism with high plasma immunoreactive growth hormone: measurement of sulfation factor, metabolic and linea growth responses. J Clin Endocrinol Metab 1971:33:332-42.

Correspondence to $T$ Tuvemo. Department of Paediatrics, Akademiska Hospital, S-751 85 Uppsala, Sweden.

Received 9 August 1985 